\title{
STUDI PENGARUH FAKTOR BUMBU, JENIS MINYAK DAN FREKUENSI PENGGORENGAN TERHADAP IMPURITIS MINYAK GORENG PASCA PENGGORENGAN TEMPE KEDELAI
}

\author{
[The Effect of Speed Factors, Oil Type and Fried Frequency of Imported Fried Oil Post Fishing of \\ Soybean Tempe]
}

Cindhe Putri Larasati*, Sri Hartati, Novian Wely Asmoro, Catur Budi Handayani

Program Studi Teknologi Hasil Pertanian, Universitas Veteran Bangun Nusantara Sukoharjo

Email: cindhelaras3@gmail.com

Diterima 15 November 2019 / Disetujui 06 Juli 2020

\begin{abstract}
The purpose of this study was to determine the effect of seasoning and type of oil on the weight of impurities and water content of oil after soybean tempeh frying, and to know the effect of frying frequency on quality of cooking oil after soybean tempeh frying with chemical and physical parameters. The experimental design used in this study was a factorial completely randomized design with two treatments No Seasoning and Seasoning. The second treatment is the frying frequency. The first factor had 18 treatments and the second factor was 12 treatments, each treatment was repeated $2 x$ so that the first factor was obtained $18 \times 2$ $=36$ units of the experiment, the second factor $12 \times 2=24$ units of the experiment. Data were analyzed statistically using F. If the test shows significantly different results, followed by HSD test. Stage I to measure water content (gravimetric method) and the weight of impurities cooking oil after frying soybean tempeh. The influence of seasoning / no seasoning and the type of oil which gives the water content and weight of impurities in the highest post-frying soybean frying oil used for stage II research. Phase II tests the water content, weight of impurities (gravimetry), specific gravity (pycnometer), free fatty acids (titration), color (chromameter). The results showed that cooking oil with no seasoning tempeh frying and no oil had a significant effect on water content, while the weight of impurities had a significant effect on tempeh results without Bulk oil seasoning (TC) $28.25 \%$ and Bulk oil-seasoned tempeh BC) $31.23 \%$. The frying frequency does not significantly affect the water content and specific gravity, but it has a significant effect on the weight of impurities with results, the frequency of 1 time frying (P1X) 30.1\%, free fatty acids with a frequency of 3 times frying (P3X) $0.40 \%$ and at a frequency of 4 times frying (P4X) $0.35 \%$ and color $L *$ at a frequency of 1 frying time (P1X) 60.54, a * with a frequency of 1 time frying (P1X) -0.51 and a frequency of 2 times the frying (P2X) 2.54, $b$ * 1 time frying frequency $(P 1 X) 29.26$.
\end{abstract}

Keywords: Frying frequency, Impurities, Oil, Oil quality

\section{ABSTRAK}

Tujuan dari penelitian ini adalah mengetahui pengaruh bumbu dan jenis minyak terhadap berat impuritis dan kadar air minyak pasca penggorengan tempe kedelai, serta mengetahui pengaruh frekuensi penggorengan terhadap mutu minyak goreng pasca penggorengan tempe kedelai dengan parameter fisik dan kimia. Metode penelitian menggunakan Rancangan Acak Lengkap. Faktor pertama menggunakan tempe berbumbu/ tidak berbumbu serta jenis minyak dan faktor kedua frekuensi penggorengan. Faktor pertama mempunyai 18 perlakuan dan faktor kedua 12 perlakuan, masing-masing perlakuan diulang $2 x$ sehingga diperoleh faktor pertama $18 \times 2=36$ unit percobaan, faktor kedua $12 \times 2=24$ unit percobaan. Data yang diperoleh dianalisis secara statistik menggunakan uji F. Apabila memperlihatkan hasil berbeda nyata, dilanjutkan dengan uji BNJ. Analisis pada tahap I yaitu kadar air (metode gravimetri) dan berat impuritis minyak goreng pasca penggorengan tempe kedelai. Tahap II menguji kadar air, berat impuritis (gravimetri), berat jenis (piknometer), asam lemak bebas (titrasi), warna (chromameter). Hasil penelitian menunjukkan bahwa minyak goreng pasca penggorengan tempe yang berbumbu/ tidak berbumbu dan jenis minyak tidak berpengaruh nyata terhadap kadar air, sedangkan terhadap berat impuritis berpengaruh nyata dengan hasil tempe tanpa bumbu minyak Curah (TC) $28,25 \%$ dan tempe berbumbu minyak Curah (BC) $31,23 \%$. Pada frekuensi penggorengan tidak berpengaruh nyata terhadap kadar air dan berat jenis, namun berpengaruh nyata terhadap berat impuritis dengan hasil, frekuensi 1 kali penggorengan (P1X) 30,1\%, asam lemak bebas dengan frekuensi 3 kali penggorengan (P3X) 0,40\% dan pada frekuensi 4 kali penggorengan (P4X) 0,35\% dan warna $L^{*}$ pada frekuensi 1 kali penggorengan (P1X) 60,54, a* dengan frekuensi 1 kali penggorengan (P1X) -0,51 dan frekuensi 2 kali penggorengan (P2X) 2,54, b* frekuensi 1 kali penggorengan (P1X) 29,26.

Kata kunci: Frekuensi penggorengan, Impuritis, Minyak, Mutu minyak 
Versi Online:

http://www.profood.unram.ac.id/index.php/profood e-ISSN: 2443-3446

\section{PENDAHULUAN}

Tempe kedelai merupakan bahan makanan hasil fermentasi kacang kedelai dengan menggunakan jamur Rhizopus oligosporus dan Rhizopus oryzae. Tempe umumnya dibuat secara tradisional dan merupakan sumber protein nabati. Tempe mudah dicerna dan diserap oleh tubuh (Dwinaningsih, 2010). Tempe diminati oleh banyak masyarakat Indonesia, karena selain harganya relatif murah dan enak rasanya, tempe juga memiliki kandungan protein nabati yangtinggi (Astuti, 2009). Tempe kedelai diketahui memiliki kandungan gizi, energi, protein, lemak, hidrat arang, serat, abu, kalsium, fosfor, besi, karotin, vitamin B1 dan air. Selain itu tempe kedelai juga memiliki kandungan asam lemak, vitamin, mineral dan antioksidan (BSN, 2012).

Berbagai olahan berbahan dasar tempe yang sering ditemui seperti gorengan, tempe mendoan, tempe bacem, tumis tempe, martabak tempe, dan juga keripik tempe (Amalia, 2015). Umumnya, masyarakat Indonesia mengkonsumsitempe sebagai panganan pendamping nasi (BSN, 2012). Olahan tempe yang paling banyak dikonsumsi adalah tempe goreng.

Penggorengan pada tempe menggunakan media minyak goreng sebagai media penghantar panas yang membuat makanan gorengan memiliki cita rasa yang lebih gurih sehingga dapat membangkitkan selera makan. Selain itu minyak goreng juga berperan sebagai sumber energi dan sumber kolesterol (Rusdiana, 2015). Penggorengan menambah kalori dalam pangan yang menyebabkan meningkatnya kandungan protein tempe goreng. Peningkatan protein pada tempe juga disebabkan terjadi proses dehidrasi (pengambilan air) dari produk pangan (Wihandini, dkk. 2012).

Proses penggorengan sering kali menyisakan minyak goreng pasca penggorengan. Penggunaan minyak goreng yang lama dan berkali- kali dapat menyebabkan ikatan rangkap teroksidasi membentuk gugus peroksida dan monomersiklik yang diikuti reaksi hidrolisis dengan adanya air dari bahan pangan. Minyak goreng yang sudah coklat kehitaman bersifat karsinogenik, cirinya minyak makin tengik. Minyak ini biasa disebut minyak jelantah (Abdullah, 2007). Minyak jelantah atau minyak yang digunakan berulang dapat menyebabkan kerusakan pada minyak goreng (Rusdiana, 2015). Kerusakan minyak goreng ini seperti adanya endapan/ impuritis. Penggorengan tempe sering kali memperlihatkan perubahan yang sangat mencolok antara minyak goreng sebelum digunakan dengan minyak goreng pasca digunakan penggorengan. Belum diperoleh informasi impuritis yang spesifik, faktor-faktor apa saja yang mempengaruhi impuritis minyak goreng pasca penggorengan tempe. Penelitian yang dilakukan oleh Alam, dkk. (2014), frekuensi pemakaian minyak goreng pengaruhnya sangat nyata terhadap perubahan warna, tekstur, kadar air, minyak, bahkan menurunkan tingkat kesukaan panelis pada produk terhadap kerenyahan bawang goreng. Jika penggorengan dilakukan lebih dari 3 kali akan menyebabkan perubahan sifat fisik dan kimiawi pada minyak goreng tersebut.

Berdasarkan penjelasan di atas, maka penelitian ini sangat penting dilaksanakan agar masyarakat dapat mengetahui berat impuritis dan mutu minyak goreng pasca penggorengan tempe kedelai. Dengan demikian, peneliti mengangkat judul "Studi Pengaruh Faktor Bumbu, Jenis Minyak dan Frekuensi Penggorengan Terhadap Impuritis Minyak Goreng Pasca Penggorengan Tempe Kedelai" sebagai penelitian.

\section{BAHAN DAN METODE}

\section{Bahan}

Bahan baku meliputi tempe kedelai, minyak goreng kualitas rendah merk (Curah), minyak goreng kualitas sedang merk (Gunung Mas), kualitas baik merk (Sunco), bawang putih, garam, ketumbar, air.Bahan yang digunakan dalam analisis kimia yaitu $\mathrm{NaOH}$, fenolftalein (pp), aquades, etanol, alkhol, nheksana. 


\section{Alat}

Alat yang digunakan dalam penggorengan tempe kedelai yaitu penggorengan (wajan), sotel, stopwatch, kompor, telenan, serok, pisau. Sedangkan alat yang digunakan dalam analisis meliputi labu takar, pipet tetes, pipet volume, buret, piknometer, beaker glass, turbidimeter, timbangan analitik,oven, desikator, crush tang, kertas saring, erlenmeyer, spiritus, kaki tiga, kawat kasa, gelas ukur, corong, thermometer, botol timbang, chromameter Konica Minolta CR-400.

\section{Metode}

Penelitian inidilakukan dalam 2 tahapan penelitian yaitu tahap Iuntuk mengetahui pengaruh tempe berbumbu/ tidak berbumbu dan jenis minyak terhadap impuritis minyak pasca penggorenan, dengan parameter pengamatan meliputi kadar air dan berat impuritis. Hasil pengamatan dari tahap I dengan nilai kadar air dan berat impuritis yang paling tinggi digunakan untuk penelitian tahap II. Penelitian tahap II ditujukan untuk mengetahui pengaruh pengulangan penggorengan terhadap impuritis minyak pasca penggorengan. Parameter pengamatan yang diukur meliputi analisis kadar air, analisis berat impuritis, berat jenis, analisis asam lemak bebasdan analisis warna.

\section{Parameter Pengamatan}

Parameter pengamatan yang digunakan untuk menganalisis minyak goreng pasca penggorengan tempe kedelai meliputi sifat kimia (kadar air (Sinaga, 2011) dan asam lemak bebas (Sinaga, 2011)) dan sifat fisik (berat impuritis (Sinaga, 2011), berat jenis (Sari, dkk., 2014) dan warna (Juwitasari, 2016)).

\section{Rancangan Penelitian}

Penelitian ini disusun dengan Rancangan Acak Lengkap. Faktor pertama berbumbu/ tidak berbumbu dan jenis minyak dan faktor kedua frekuensi penggorengan. Faktor pertama mempunyai 18 perlakuan dan faktor kedua 12 perlakuan, masing-masing perlakuan diulang $2 x$ sehingga diperoleh faktor pertama $18 \times 2=36$ unit percobaan, faktor kedua $12 \times 2=24$ unit percobaan. Data yang diperoleh dianalisis secara statistik menggunakan uji F. Apabila memperlihatkan hasil berbeda nyata, dilanjutkan dengan uji BNJ.

\section{HASIL DAN PEMBAHASAN}

\section{Pengaruh Bumbu dan Jenis Minyak Kadar Air}

Hasil dari analisis kadar air minyak goreng pasca penggorenganmenunjukkan nilai dari kadar air berturut-turut sebesar $\mathrm{TC}=$ $0,033 \%, \quad \mathrm{TGM}=0,033 \%, \mathrm{TS}=0,02 \%, \quad \mathrm{BC}=$ $0,035 \%, B G M=0,033 \%$ dan $B S=0,025 \%$. Hasil pengujian statistik menunjukkan bahwa faktor bumbu dan jenis minyak tidak berpengaruh nyata $(P>0,05)$ terhadap kadar air.Kadar air pada minyak goreng pasca penggorengan tempe kedelai dengan variasi bumbu/tidak berbumbu dan jenis minyak goreng dapat dilihat pada grafik Gambar 1.

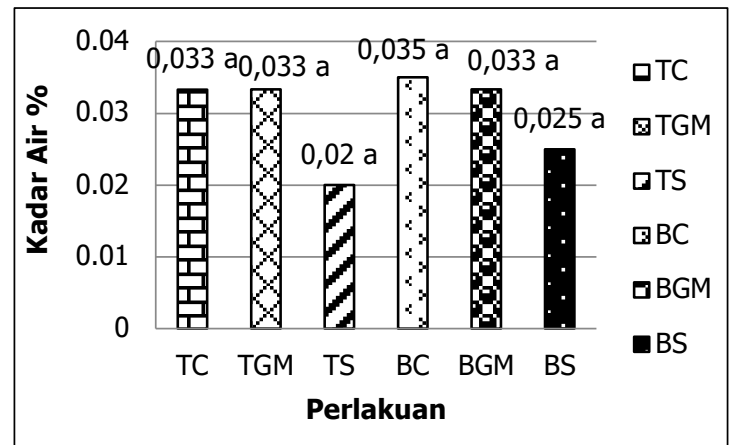

Gambar 1. Kadar air minyak goreng pasca penggorengan tempe kedelai dengan variasi bumbu/tidak berbumbu dan jenis minyak goreng.

Keterangan: ( $\mathrm{TC}=$ Tanpa bumbu Curah, $\mathrm{TGM}=$ Tanpa bumbu Gunung Mas, TS= Tanpa bumbu Sunco, $B C=$ Berbumbu Curah, BGM= Berbumbu Gunung Mas, BS= Berbumbu Sunco).

Hasil analisis menunjukkan sampel yang mempunyai kadar air terendah 0,02\% yaitu pada perlakuan TS dan yang paling tinggi pada perlakuan BC yaitu 0,035\%. Berdasarkan hasil analisis tahap I menunjukkan bahwa perlakuan BC yang 
memiliki kadar air tinggi pada minyak goreng pasca penggorengan tempe kedelai.

\section{Berat Impuritis}

Berat impuritis dihitung berdasarkan sampel minyak yang telah diuapkan kadar airnya. Hasil pengujian statistik menunjukkan bahwa faktor berbumbu/tidak berbumbu dan jenis minyak berpengaruh nyata $(P<0,05)$ terhadap berat impuritis.

Berdasarkan hasil analisis enam sampel minyak goreng pasca penggorengan tahap I, berat impuritisminyak memiliki kisaran antara 23,95\%-31,233\% dengan berat impuritis terkecil dimiliki oleh sampel minyak TS dan berat impuritis terbesar dimiliki oleh sampel minyakBC. Berat impuritis pada minyak goreng pasca penggorengan tempe kedelai dengan variasi bumbu/tidak berbumbu dan jenis minyak goreng dapat dilihat pada grafik Gambar 2.

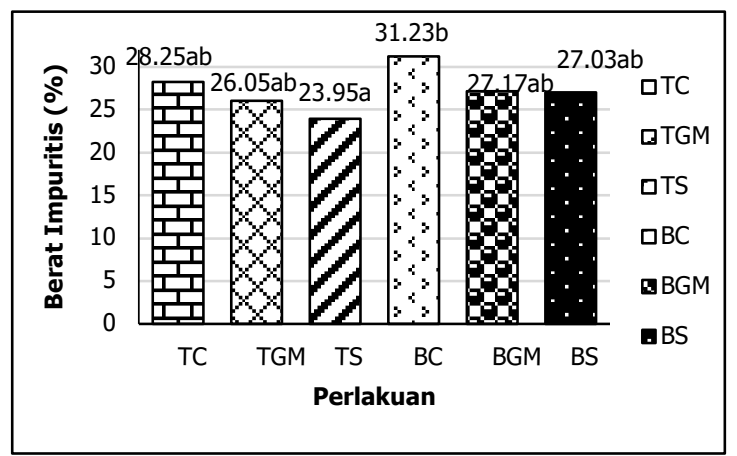

Gambar 2. Berat impuritis minyak goreng pasca penggorengan tempe kedelai dengan variasi bumbu/tidak berbumbu dan jenis minyak goreng.

Keterangan: $(\mathrm{TC}=$ Tanpa bumbu curah, $\mathrm{TGM}=$ Tanpa bumbu gunung mas, $\mathrm{TS}=$ Tanpa bumbu sunco, $\mathrm{BC}=$ Berbumbu Curah, BGM= Berbumbu Gunung Mas, BS= Berbumbu Sunco).

Dari hasil analisis menunjukkan bahwa berat impuritis tertinggi pada perlakuan BC $31,233 \%$, maka perlakuan BC yang akan digunakan untuk penelitian tahap II, karena sampel BC menghasilkan berat impuritis tertinggi yang menunjukkan mutu minyak goreng pasca penggorengan tempe kedelai yang paling rendah. Meningkatnya impuritis pada proses penggorengan berasal dari akumulasi perubahan akibat trigliserida teroksidasi, air, asam lemak bebas dari minyak goreng tersebut (Alam, dkk. 2014)

\section{Pengaruh Frekuensi Penggorengan Kadar Air}

Menurut Nurhidayati (2010), Kadar air adalah banyaknya kandungan air yang terdapat di dalam sampel yang dapat mempengaruhi mutu dan daya simpan dari bahan pangan. Analisis kadar air menggunakan metode pemanasan/ gravimetri.

Nilai kadar air minyak yang dianalisis berada di bawah nilai kadar air dalam syarat mutu SNI 01-3741-2002.Sampel yang mempunyai kadar air terendah pada perlakuan $\mathrm{P} 2 \mathrm{X}$ 0,025\% dan yang paling tinggi pada perlakuan $\mathrm{P} 3 \mathrm{X} 0,047 \%$. Hasil pengujian statistik menunjukkan bahwa frekuensi penggorengan tidak berpengaruh nyata $(P>0,05)$ terhadap kadar air. Kadar air pada minyak goreng pasca penggorengan tempe kedelai dengan variasi frekuensi penggorengan dapat dilihat pada grafik Gambar 3.

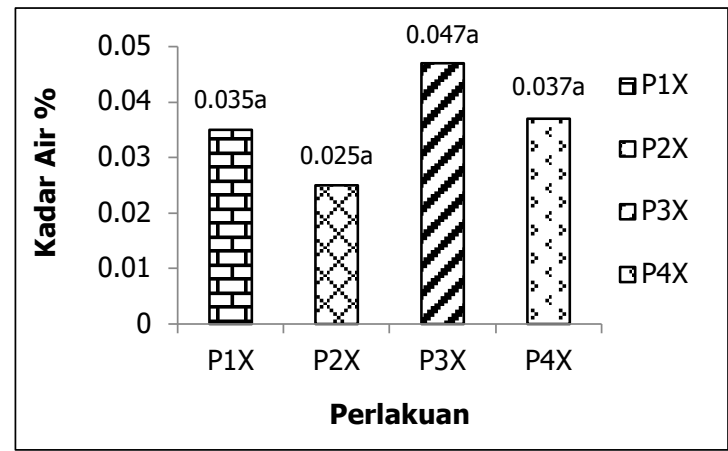

Gambar 3. Kadar air minyak goreng pasca penggorengan tempe kedelai dengan variasi frekuensi penggorengan.

Keterangan: ( $\mathrm{P} 1 \mathrm{X}=$ Frekuensi 1 kali penggorengan, $\mathrm{P} 2 \mathrm{X}=$ Frekuensi 2 kali penggorengan, P3X= Frekuensi 3 kali penggorengan, $\mathrm{P} 4 \mathrm{X}=$ Frekuensi 4 kali penggorengan).

Perubahan kadar air terjadi selama proses menggoreng, air dalam bahan pangan akan keluar dan diisi oleh minyak goreng sehingga menaikkan kadar air dalam minyak dan juga dapat menurunkan kadar air dalam 
produk karena proses penguapan yang terjadi serta masuknya minyak kedalam produk tersebut (Ratnaningsih, dkk., 2007; Chalid, dkk., 2008 dan Suroso, 2013).

\section{Berat Impuritis}

Impuritis digunakan untuk mengetahui berat kotoran yang terdapat dalam minyak gorengpasca penggorengan tempe kedelai. Berat impuritis dapat diartikan sebagai berat kotoran/ endapan pada minyak pasca penggorengan. Sampel yang digunakan untuk analisis berat impuritis ini menggunakan sampel yang telah diuapkan kadar airnya. Berat impuritis minyak goreng pasca penggorengan tempe kedelai dengan variasi frekuensi penggorengan dapat dilihat padagrafik Gambar 4.

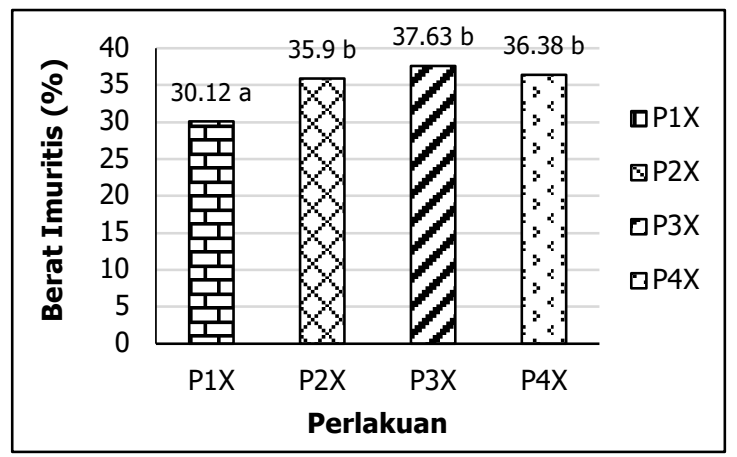

Gambar 4. Berat impuritis minyak goreng pasca penggorengan tempe kedelai dengan variasi frekuensi penggorengan.

Keterangan: $(\mathrm{P} 1 \mathrm{X}=$ Frekuensi 1 kali penggorengan, $\mathrm{P} 2 \mathrm{X}=$ Frekuensi 2 kali penggorengan, P3X= Frekuensi 3 kali penggorengan, $\mathrm{P} 4 \mathrm{X}=$ Frekuensi 4 kali penggorengan).

Nilai berat impuritisempat sampel minyak yang dianalisis berada di atas nilai kadar kotoran maksimal $0,5 \%$ dalam syarat mutu SNI 01-2901-2006. Hasil pengujian statistik menunjukkan bahwa frekuensi penggorengan berpengaruh nyata $(P<0,05)$ terhadap berat impuritis. Hasil dari analisis berat impuritisdengan menggunakan frekuensi penggorengan $\mathrm{P} 1 \mathrm{X}, \mathrm{P} 2 \mathrm{X}, \mathrm{P} 3 \mathrm{X}$ dan P4X berkisar antara 30,1-37,6 \%. Nilai dari berat impuritis berturut-turut sebesar $30,1 \%$, $35,9 \%, 37,6 \%$ dan $36,4 \%$. Sampel yang mempunyai kadar kotoran tertinggi pada perlakuan P3X $37,6 \%$ dan yang terendah sampel dengan perlakuan P1X 30,1\%. Dari hasil frekuensi penggorengan tempe kedelai meningkatkan kadar impuritis sehingga mutu minyak semakin rendah.

\section{Berat Jenis}

Berat jenis suatu zat adalah perbandingan antara bobot zat dibandingkan dengan volume zat pada suhu tertentu (biasanya pada suhu $25^{\circ} \mathrm{C}$ ) (Ahmad, dkk., 2014). Penentuan berat jenis minyak goreng menggunakan Piknometer.Berat jenis minyak goreng pasca penggorengan tempekedelai dengan variasi frekuensi penggorengan dapat dilihat pada grafik Gambar 5.

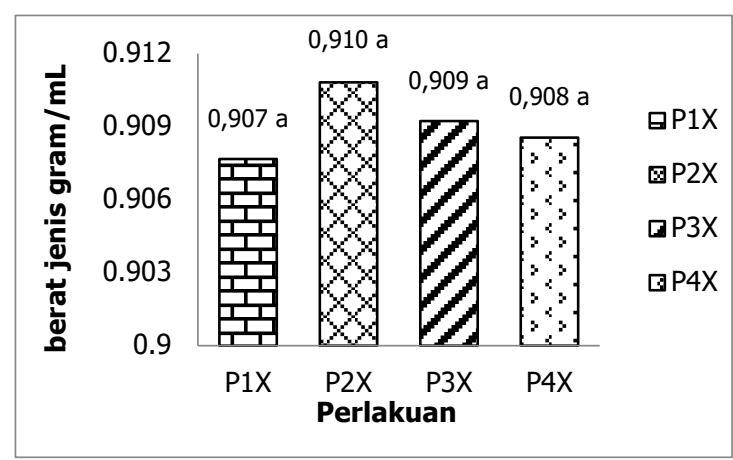

Gambar 5. Berat jenis minyak goreng pasca penggorengan tempe kedelai dengan variasi frekuensi penggorengan.

Keterangan: ( $\mathrm{P} 1 \mathrm{X}=$ Frekuensi 1 kali penggorengan, $\mathrm{P} 2 \mathrm{X}=$ Frekuensi 2 kali penggorengan, P3X= Frekuensi 3 kali penggorengan, $\mathrm{P} 4 \mathrm{X}=$ Frekuensi 4 kali penggorengan).

Menurut Standar Mutu Minyak Goreng Berdasarkan SNI 01-3741-1995 berat jenis minyak 0,921 gram $/ \mathrm{ml}$. Jika dilihat dari berat jenis menurut SNI minyak goreng maka berat jenis minyak dari hasil penelitian ini mendekati nilai berat jenis menurut SNI minyak goreng. Berat jenis terendah 0,907 gram/ml didapat dari perlakuan pada P1X.

Hasil pengujian statistik menunjukkan bahwa frekuensi penggorengan tidak berpengaruh nyata $(P>0,05)$ terhadap berat jenis. Peningkatan berat jenis berbanding lurus dengan banyaknya frekuensi dalam menggoreng. Semakin sering penggorengan dilakukan, semakin terhidrolisis minyak tersebut yang mengakibatkan berat jenis semakin besar. Hasil hidrolisis terhadap minyak menghasilkan senyawa gliserol dan 
asam lemak yang memiliki berat molekul lebih besar dibandingkan dengan minyak (trigliserida) yang belum digunakan untuk menggoreng, sehingga berat jenis minyak goreng semakin besar (Sari, dkk., 2014).

\section{Asam Lemak Bebas}

Asam lemak bebas adalah asam lemak yang berada sebagai asam bebas tidak terikat sebagai trigliserida. Asam lemak bebas dihasilkan oleh proses hidrolisis dan oksidasi, biasanya bergabung dengan lemak netral. Jumlah asam lemak bebas yang terdapat dalam minyak dapat menunjukkan kualitas minyak, dimana semakin tinggi nilai asam lemak bebas maka semakin turun kualitas. Hasil reaksi hidrolisis minyak sawit adalah gliserol dan asam lemak bebas. Reaksi ini akan dipercepat dengan adanya faktor-faktor panas, air, keasaman, dan katalis (enzim). Semakin lama reaksi ini berlangsung, maka semakin banyak kadar asam lemak bebas yang terbentuk (Utami, 2018 dan Sumarlin, dkk., 2008).

Peningkatan kadar asam lemak bebas menandakan penurunan kualitas minyak goreng selama penggorengan. Peningkatan kandungan asam lemak bebas selama penggorengan disebabkan karena akibat terjadinya reaksi oksidasi dan hidrolisa minyak selama proses penggorengan.

Asam lemak bebas terbentuk karena terjadinya hidrolisa minyak menjadi asamasamnya. Adanya air yang terdapat dalam penggorengan dapat menyebabkan reaksi hidrolisa yang mengakibatkan ketengikan. Selama proses penggorengan minyak mengalami reaksi degradasi yang disebabkan oleh panas, air dan udara sehingga menyebabkan terjadinya oksidasi, hidrolisis dan polimerisasi (Putri, dkk., 2016). Asam lemak bebasminyak goreng pasca penggorengan tempe kedelai dengan variasi frekuensi penggorengan dapat dilihat pada grafik Gambar 6.

Proses penggorengan pada penelitian ini dilakukan tidak terputus/berkelanjutan sehingga rendahkan asam lemak bebas dapat disebabkan karena asam-asam lemak bebas pendek yang memiliki sifat volatil, dengan semakin banyaknya frekuensi penggorengan diduga mengurangi kadar asam lemak bebas. Keberadaan air pada minyak akan mempercepat proses hidrolisis dari minyak goreng. Semakin lama penggunan minyak untuk menggoreng semakin tinggi pula kandungan asam lemak bebas yang terbentuk. Dari data diatas, kadar asam lemak bebas yang tertinggi mencapai $0,528 \%$ yang berarti sudah melewati ambang batas persentase asam lemak bebas yang ditetapkan oleh SNI 01-3741-1995 yang berisi syarat kandungan asam lemak bebas maksimal $0,30 \%$. Hasil pengujian statistik menunjukkan bahwa frekuensi penggorengan berpengaruh nyata $(P<0,05)$ terhadap asam lemak bebas. menurut penelitian Alam, dkk (2014), pemakaian minyak goreng lebih dari 3 kali pada proses penggorengan bawang merah, menyebabkan asam lemak bebas telah teroksidasi sehingga kurang layak untuk digunakan kembali.

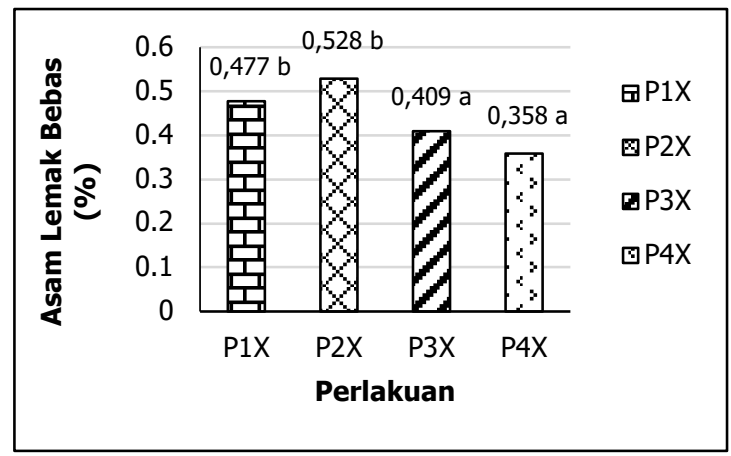

Gambar 6. Asam lemak bebas minyak goreng pasca penggorengan tempe kedelai dengan variasi frekuensi penggorengan.

Keterangan: ( $\mathrm{P} 1 \mathrm{X}=$ Frekuensi 1 kali penggorengan, $\mathrm{P} 2 \mathrm{X}=$ Frekuensi 2 kali penggorengan, P3X= Frekuensi 3 kali penggorengan, $\mathrm{P} 4 \mathrm{X}=$ Frekuensi 4 kali penggorengan).

\section{Warna}

Warna bahan pangan merupakan salah satufaktor penentu mutu. Sebelum faktor lain dipertimbangkan,warna terlebih dahulu tampil dan kadang-kadang sangat menentukan penerimaan konsumen (Alam, dkk., 2014). Hasil penelitian menunjukan bahwa perlakuan P1X mempunyai nilai $L^{*}$ 
(lightness/kecerahan) yang tertinggi yakni 60,545 mendekati tingkat cerah, sedangkan P4X menunjukan nilai $L^{*}$ yang terendah yakni 52,67 . Analisis statistik menunjukkan bahwa tingkat kecerahan minyak goreng $\mathrm{P} 1 \mathrm{X}$ sangat berbeda nyata $(p<0,05)$. Secara statistik tingkat kecerahan $\mathrm{P} 3 \mathrm{X}$ dan $\mathrm{P} 4 \mathrm{X}$ tidak berbeda nyata $(p>0,05)$. Nilai $a *((+)$ merah/ $(-)$ hijau) yang terendah $\mathrm{P} 1 \mathrm{X}$ yakni $-0,51$ dan tertinggi $P 4 X$ yakni 3,93. Hasil analisis statistik menunjukkan P1X berbeda nyata $(p<0,05)$, sedangkan P3X dan P4X tidak berbeda nyata $(p>0,05)$. Warna minyak goreng pasca penggorengan tempe kedelai dengan variasi frekuensi penggorengan dapat dilihat pada Tabel 1.

Tabel 1. Warna minyak goreng pasca penggorengan tempe kedelai dengan variasi frekuensi penggorengan.

\begin{tabular}{|l|l|l|c|}
\hline \multirow{2}{*}{ Perlakuan } & \multicolumn{3}{|c|}{ Warna } \\
\cline { 2 - 4 } & \multicolumn{1}{|c|}{ L* } & \multicolumn{1}{|c|}{ a* } & b* \\
\hline P1X & $60,54 \mathrm{c}$ & $-0,51 \mathrm{a}$ & $29,26 \mathrm{a}$ \\
\hline P2X & $55,92 \mathrm{~b}$ & $2,54 \mathrm{~b}$ & $32,87 \mathrm{~b}$ \\
\hline P3X & $54,41 \mathrm{ab}$ & $3,70 \mathrm{c}$ & $33,80 \mathrm{~b}$ \\
\hline P4X & $52,67 \mathrm{a}$ & $3,92 \mathrm{c}$ & $34,14 \mathrm{~b}$ \\
\hline
\end{tabular}

Ket: $\quad(\mathrm{P} 1 \mathrm{X}=$ Frekuensi 1 kali penggorengan, $\mathrm{P} 2 \mathrm{X}=$ Frekuensi 2 kali penggorengan, P3X= Frekuensi 3 kali penggorengan, $\mathrm{P} 4 \mathrm{X}=$ Frekuensi 4 kali penggorengan).

Hasil analisis statistik nilai $b^{*}$ menunjukkan bahwa tingkat kekuningan minyak goreng berbeda nyata $(p<0,05)$. Perubahan warna pada minyak goreng menjadi warna gelap dapat terjadi selama proses pengolahan dan penyimpanan, yang disebabkan oleh beberapa faktor, yaitu: suhu pemanasan yang terlalu tinggi pada waktu penggorengan sehingga minyak terksidasi (Chairunisa, 2013).

Perubahan warna minyak goreng dapat terjadi selama proses pengolahan dan disebabkan oleh suhu pemanasan yang terlalu tinggi. Pemanasan yang lama dan berulangulang akan mempercepat terjadinya hidrolisis, oksidasi, dan penguraian minyak menjadi karbon. Selain itu, minyak yang teroksidasi akan memberikan perubaan warna minyak goreng yang terlihat secara visual, ini disebabkan terdapat senyawa-senyawa volatil yang akan menguap selama proses penggrengan berlangsung, sehingga menyebabkan intensitas warna pada minyak goreng menajdi semakin gelap (Sari, dkk., 2014).

\section{KESIMPULAN}

Bumbu dan jenis minyak tidak berpengaruh nyata terhadap kadar air minyak goreng pasca penggorengan tempe kedelai, tetapi berpengaruh nyata terhadap berat impuritis minyak goreng pasca penggorengan tempe kedelai. Frekuensi penggorengan tidak berpengaruh nyata terhadap kadar air dan berat jenis minyak goreng pasca penggorengan tempe kedelai tetapi berpengaruh nyata terhadap berat impuritis, asam lemak bebas dan warna minyak goreng pasca penggorengan tempe kedelai yang menyebabkan mutu minyak goreng semakin rendah.

\section{DAFTAR PUSTAKA}

Abdullah. 2007. Pengaruh Gorengan dan Intensitas Penggorengan Terhadap Kualitas Minyak Goreng. Jurnal Pilar Sains 6(2): 46-50.

Ahmad, D., Sari, P.N., dan Gilang, P.R. 2014. Uji Kualitas Minyak Kelapa Dengan Uji Coba Penggorengan. Jurnal Teknologi Pengolahan Minyak dan Lemak.

Alam, N., Rstiati, dan Muhardi. 2014. Sifat Fisik-Kimia dan Organoleptik Bawang Palu Pada Berbagai Frekuensi Pemakaian Minyak Goreng. Jurna Agritech 34(4): 390-398.

Amalia, T.R.N. 2015. Perbedaan Teknik Penggorengan Terhadap Kadar Protein Terlarut dan Daya Terima Keripik Tempe. Naskah Publikasi. Universitas Muhammadiyah Surakarta.

Astuti, N.P. 2009. Sifat Organoleptik Tempe Kedelai Yang Dibungkus Plastik, Daun Pisang dan Daun Jati. Karya Tulis IImiah. Universitas Muhammadiyah Surakarta.

BSN. 2012. Tempe. http://www.bsn.go.id/uploads/downloa 
Versi Online:

http://www.profood.unram.ac.id/index.php/profood e-ISSN: 2443-3446

d/Booklet_tempe-printed21.pdf.Diakses Pada Tanggal 28 Februari 2019.

Chairunisa. 2013. Uji Kualitas Minyak Goreng Pada Pedagang Gorengan Di Sekitar Kampus UIN Syarif Hidayatullah Jakarta. Skripsi. UIN Syarif Hidayatullah Jakarta.

Chalid, S.Y., Muawanah, A., dan Jubaedah, I. 2008. Analisa Radikal Bebas Pada Minyak Goreng Pedagang Gorengan Kaki Lima. Jurnal Valensi 1(2): 82-86.

Dwinanigsih, E.A. 2010. Karakteristik Kimia dan Sensori Tempe Dengan Variasi Bahan Baku Kedelai/Beras dan Penambahan Angkak Serta Variasi Lama Fermentasi. Skripsi. Universitas Sebelas Maret.

Juwitasari, M.M. 2016. Pengukuran Perubahan Warna Pada Pencoklatan Kukis Selama Pemanggangan Dengan Kamera Digital. Skripsi. Institusi Pertanian Bogor.

Nurhidayati, R. 2010. Analisa Mutu Kernel Palm Dengan Parameter Kadar Alb (Asam Lemak Bebas), Kadar Air Dan Kadar Zat Pengotor Di Pabrik Kelapa Sawit Pt. Perkebunan Nusantara-V Tandun Kabupaten Kampar. Skripsi. Universitas Islam Negeri Sultan Syarif Kasim Riau Pekanbaru.

Putri, R.I., Budiyanto dan Syafnil. 2016. Kajian Kualitas Minyak Goreng pada Penggorengan Berulang Ikan Lemuru (Sardienella Lemuru). Jurnal Agroindustri 6(1): 1-7.

Ratnaningsih, Rahajo, B. dan Suhargo. 2007. Kajian Penyerapan Air dan Penguapan Minyak pada Penggorengan Ubi Jalar (Ipomoea batatas $\mathrm{L}$ ) dengan Metode Deep-Fat Frying. Jurnal Agritech 27(1).

Rusdiana, R. 2015. Analisis Kualitas Minyak Goreng Berdasarkan Parameter Viskositas dan Indeks Bias. Skripsi. Universitas Islam Negeri Walisongo Semarang.

Sari, L.N.I., Nurlita, F., dan Maryam, S. 2014. Analisis Kualitas Minyak Goreng Yang Digunakan Pedagang Ayam Goreng Kaki Lima Di Singaraja. Jurnal Kimia Visvitalis 2(1): 99-106.
Pro Food (Jurnal Ilmu dan Teknologi Pangan)

Vol 6 No. 1 Mei 2020

ISSN: 2443-1095

Sinaga, R.A. 2011. Kajian Mutu Minyak Sawit Kasar dan Analisis Karakteristik Olein Serta Stearin Sebagai Hasil Fraksinya. Skripsi. Institusi Pertanian Bogor.

Sumarlin, L.A., Mukmillah, L., dan Istianah, R. 2008. Analisis Mutu Minyak Jelantah Hasil Peremajaan Menggunakan Tanah Diatomit Alami dan Terkalsinasi. Jurnal. Hal. 171-180.

Suroso, A.S. 2013. Kualitas Minyak Goreng Habis Pakai Ditinjau dari Bilangan Peroksida, Bilangan Asam dan Kadar Air. Jurnal Kefarmasian Indonesia 3(2): 77-88.

Utami, R. 2018. Penentuan Kadar Air dan Asam Lemak Bebas Dalam Minyak Goreng Yang Beredar Dipasaran Kec. Medan Selayang. Karya IImiah. Universitas Sumatera Utara.

Wihandini, D.A., Arsanti, L., Wijanarka, A. 2012. Sifat Fisik, Kadar Protein, dan Uji Organoleptik Tempe Kedelai Hitam dan Tempe Kedelai Kuning Dengan Berbagai Metode Pemasakan. Jurnal Gizia 14(1): 34-42. 